\title{
In vitro Efficacy of Fungicides and Bio-Control Agents against Wilt of Chickpea Caused by Fusarium oxysporum f. sp. ciceris (Foc)
}

\author{
Sabiya Bashir ${ }^{1}$, Mohammad Najeeb Mughal ${ }^{2}$, Sher A. Dar ${ }^{1}$, Seerat un Nissa ${ }^{1}$, \\ Shafeeq Hakeem ${ }^{1}$, R.A. Wani ${ }^{1}$, J.A. Baba ${ }^{1}$ and Mehfooza Habib ${ }^{1}$ \\ ${ }^{1}$ Dryland Agriculture Research Station, Sher-i-Kashmir University of Agricultural Sciences and \\ Technology of Kashmir, Shalimar, Srinagar-190025, India \\ ${ }^{2}$ Faculty of Agriculture and Regional Research Station Wadura, SKUAST-K, India \\ *Corresponding author
}

A B S T R A C T

\begin{tabular}{|l|}
\hline Ke y w o r d s \\
Chickpea, Bio-control \\
agent, Fungicides, \\
Fusarium oxysporum \\
f. sp. ciceris, \\
Trichoderma.
\end{tabular}

\section{Introduction}

Chickpea (Cicer arietinum) is an important pulse crop of family Leguminaceae and ranks third in the global farming. Chickpea was orginated from west Asia and now it is cultivated in 55 countries of the world. Worldwide it is grown on an area of 13.5 million ha with an annual production of more than 13 million tonnes. It is an important crop of Indian sub-continent that usually contributes more than 66 per cent in terms of global production, while Pakistan ranks $7^{\text {th }}$ and produced 2.5 per cent of world production (Anonymous, 2013). Chickpea crop is affected by several pathogens but wilt 
caused by Fusarium oxysporum f.sp. ciceris is the most serious disease and causes huge losses upto 100 per cent if the crop remains untreated (Dubey etal.,2007).Annual yield losses in chickpea crop were estimated to be 4.8 million tonnes worldwide due to abiotic and biotic stresses, including infectious diseases(Ryan,1997).Under severe conditions, the wilt disease can damage the crop completely and causes losses upto $100 \%$ (Navas-cortes et al.,2000). However, yield losses of 10-15 per cent were reported as a regular feature of this severe disease (Campbell and Madden, 1990). In India, annual yield losses of 10 percent were reported (Trapero-Cases and Jimenez-diaz, 1985) due to this wilt disease. Chickpea wilt is a vascular pathogen that perpetuates both in seed as well as soil. In absence of the host, the pathogen can also survive upto 3- 6 years (Ayyub et al.,2003). This pathogen can cause infection at all the stages of plant growth with more severe at flowering and poding stage. Wilted plants showed drooping and yellowing of leaves and lie down on the ground. The fungus invades the root system, made its way through the epidermis, cortex and finally enter into xylem vessels of tap root from where it spread. As a result, the later roots might wither off as reported by Chavan et al., 2009. Eighty per cent of plant mortality has been reported by Govil and Rana, 1994, when there is relatively high temperature with drought conditions. As a result of wilt infection, the complete plant or plant part may die within few weeks of infection. Under field conditions, the typical wilting can be appeared within 3-4 weeks after sowing, if the variety is susceptible (Haware, 1990). Thus the disease can be effectively managed through different strategies such as use of resistant varieties, cultural practices, use of fungicides and through bio-control agents. Although each of these methods of disease management practices has their own importance, but none of the method give completely success when applied alone for disease control (Chandel \& Deepika, 2010). Despite many attempts to control chickpea wilt pathogen Foc, theproblemis still important throughout the world. The use of fungicide is most effective and reliable method of controlling disease. Now economical and eco-friendly control measures are available to combat this threat (Bakhsh et $a l ., 2007)$. Fungicides with novel chemistry are being introduced and evaluated against this wilt pathogen. Their application in the farmers field can only be recommended against the Foc pathogen after a successful laboratory evaluation. It is therefore, needs a constant watch and effort to evolve new fungicides along with some non-chemical method of controlling the wilt disease (Jamil and Kumar, 2010). Therefore, the present study is carried out to evaluate non- systemic fungicides and systemic and some bio-control agents against the disease and the results are presented herein.

\section{Materials and Methods}

The systemic and non-systemic fungicides were evaluated in-vitro against chickpea blight (Fusarium oxysporum f. sp. ciceris)

\section{In-vitro evaluation of fungicides}

The non-systemic fungicides were evaluated at 50, 100, 250, 500 and $1000 \mu \mathrm{g} \mathrm{ml}^{-1}$ and systemic fungicides at 50,100, 200, 400 and $500 \mu \mathrm{g} \mathrm{ml}^{-1}$ through poisoned food technique (Carpenter, 1942) using potato dextrose agar medium for their effects on inhibition of mycelial growth. The required concentrations of fungicides were prepared by adding appropriate amount of fungicides to sterilized molten PDA medium in conical flasks. Thirty millilitre of such amended PDA was aseptically poured in sterilized Petri plates. A $5 \mathrm{~mm}$ diameter mycelial disc of FOC was aseptically placed in the centre of each Petri 
plate. Petri plates containing PDA media amended with equal amount of sterilized distilled water and inoculated with mycelial disc of Fusarium oxysporum f. sp. ciceris (5 $\mathrm{mm}$ diameter) served as check. Each treatment was replicated thrice and incubated at $28 \pm 2{ }^{\circ} \mathrm{C}$ for $48 \mathrm{hrs}$. The comparative efficacy of fungicides was calculated as per cent inhibition of mycelial growth of the test fungus in each treatment as compared to check by the following formula:

$$
\mathrm{C}-\mathrm{T}
$$

Per cent mycelial

Growth inhibition $=-\frac{-----------}{C} 100$

Where

$\mathrm{C}=$ Radial mycelial growth $(\mathrm{mm})$ in check

$\mathrm{T}=$ Radial mycelial growth in the treatment (mm)

\section{In-vitro evaluation of bio-control agents}

The pure culture of antagonistic organisms i.e. Trichoderma viridi 1, Trichoderma viridi 2, Trichoderma viridi 3, Trichoderma viridi 4, and Trichoderma harzianum 1 and Trichoderma harzianum 2 were collected from soils of different parts of Kashmir. The pure culture was multiplied in the test tubes slants. Agar slants of these cultures were placed in refrigerator at 4 degree centigrade. For in vitro assay $5 \mathrm{~mm}$ mycelial disc of both the bio-control microorganism and the pathogen were simultaneously inoculated at the opposite ends of the petriplates, containing about $20 \mathrm{ml}$ of PDA medium. Three petri plates were used for each biological control agent and the same number was kept as control. Inoculated plates were incubated at $25^{ \pm} 2^{\circ} \mathrm{C}$. For $7-10$ days. The data regarding the fungal hyphal growth were recorded by following percent growth Inhibition formula (already described above).

\section{Results and Discussion}

\section{In-vitro evaluation of non-systemic fungicides on mycelial growth inhibition}

Five non-systemic fungicides were evaluated in-vitro for inhibition of mycelium growth the pathogen (Fusarium oxysporum $\mathrm{f}$. sp. ciceris). The data (Table 1; Fig. 1) revealed that all the test fungicides significantly inhibited the mycelial growth at all the test concentrations. On an overall mean basis, both dodine 65 WP and captan 50WP proved most effective exhibiting mean mycelial growth inhibition of 66.13 per cent followed by mancozeb 75 WP 51.42 per cent mean inhibition of mycelial growth while antracol $70 \mathrm{WP}$ caused 41.75 per cent mean inhibition of mycelial growth, respectively. Copper oxychloride proved least effective resulting in only 23.79 per cent mean inhibition of mycelial growth. In general, the efficacy of fungicides varied significantly with change in fungicide concentration. At $50 \mu \mathrm{g} \mathrm{ml}^{-1}$ concentration, the mean mycelial growth inhibition was 31.16 per cent which increased to 37.96 , 44.63, 53.95 and 69.12 per cent at 100, 250, 500 and $1000 \mu \mathrm{g} \mathrm{ml}{ }^{-1}$ concentrations, respectively.

The highest mycelial growth inhibition at 50 $\mu \mathrm{g}$ a.i $\mathrm{ml}^{-1}$ concentration was exhibited by both dodine $65 \mathrm{WP}$ and captan $50 \mathrm{WP}$ exhibiting 45.23 per cent mean mycelial inhibition followed mancozeb 75 WP causing 36.16 per cent mean mycelial inhibition while copper oxychloride 50 WP was least efficacious and resulted in only 18.50 per cent mean mycelial inhibition. At $1000 \mu \mathrm{g} \mathrm{ml}^{-1}$ concentration, 100.00 per cent mycelial growth inhibition was again caused by dodine $65 \mathrm{WP}$ and captan $50 \mathrm{WP}$ followed by mancozeb 75 WP (76.40\%) while copper oxychloride 50 WP was least effective and resulted in only 30.80 per cent inhibition at the same concentration. 
Table.1 In-vitro evaluation of non-systemic fungicides against Fusarium oxysporum $\mathrm{f}$. sp ciceris (Foc) causing wilt/root rot of chickpea

\begin{tabular}{|c|c|c|c|c|c|c|}
\hline Fungicides & \multicolumn{6}{|c|}{$\begin{array}{l}\text { Per cent inhibition of radial mycelial growth at concentration } \\
\qquad\left(\mu \mathrm{g} \mathrm{ml}^{-1}\right)\end{array}$} \\
\hline & 50 & 100 & 250 & 500 & 1000 & Mean \\
\hline Anrtacol $70 \mathrm{WP}$ & $\begin{array}{l}27.92 \\
(31.89)\end{array}$ & $\begin{array}{l}30.94 \\
(37.87)\end{array}$ & $\begin{array}{l}37.30 \\
(37.87)\end{array}$ & $\begin{array}{l}49.33 \\
(44.61)\end{array}$ & $\begin{array}{l}62.90 \\
(52.49)\end{array}$ & $\begin{array}{l}41.75 \\
(40.25)\end{array}$ \\
\hline Captan 50WP & $\begin{array}{l}45.23 \\
(42.26)\end{array}$ & $\begin{array}{l}51.80 \\
(46.03)\end{array}$ & $\begin{array}{l}61.66 \\
(51.75)\end{array}$ & $\begin{array}{l}72.00 \\
(58.05)\end{array}$ & $\begin{array}{l}100.00 \\
(90.00)\end{array}$ & $\begin{array}{l}66.13 \\
(54.14)\end{array}$ \\
\hline $\begin{array}{l}\text { Copper } \\
\text { oxychloride } 50 \mathrm{WP}\end{array}$ & $\begin{array}{l}18.50 \\
(25.47)\end{array}$ & $\begin{array}{l}20.00 \\
(26.56)\end{array}$ & $\begin{array}{l}24.20 \\
(29.46)\end{array}$ & $\begin{array}{l}25.46 \\
(30.30)\end{array}$ & $\begin{array}{l}30.80 \\
(33.70)\end{array}$ & $\begin{array}{l}23.79 \\
(29.19)\end{array}$ \\
\hline Dodine $65 \mathrm{WP}$ & $\begin{array}{l}45.23 \\
(42.26)\end{array}$ & $\begin{array}{l}51.80 \\
(46.03)\end{array}$ & $\begin{array}{l}61.66 \\
(51.75)\end{array}$ & $\begin{array}{l}72.00 \\
(58.05)\end{array}$ & $\begin{array}{l}100.00 \\
(90.00)\end{array}$ & $\begin{array}{l}66.13 \\
(100.00)\end{array}$ \\
\hline Mancozeb 75 WP & $\begin{array}{l}36.16 \\
(36.96) \\
\end{array}$ & $\begin{array}{l}41.40 \\
(40.40)\end{array}$ & $\begin{array}{l}46.80 \\
(43.16) \\
\end{array}$ & $\begin{array}{l}56.36 \\
(48.65) \\
\end{array}$ & $\begin{array}{l}76.40 \\
(60.93)\end{array}$ & \\
\hline \multicolumn{7}{|l|}{ Mean } \\
\hline $\begin{array}{l}\mathrm{CD}(\mathrm{P}=0.05) \\
\text { Fungicide } \\
\text { Concentration } \\
\text { Fungicide } \times \text { Concen }\end{array}$ & ration & $\begin{aligned} & =(0.90) \\
= & (0.91) \\
= & (2.24)\end{aligned}$ & & & & \\
\hline
\end{tabular}

Figures within parentheses are arc sign transformed values

Table.2 In-vitro evaluation of systemic fungicides against Fusarium oxysporum f. sp ciceris (Foc) causing wilt/root rot of chickpea

\begin{tabular}{|c|c|c|c|c|c|c|}
\hline \multirow[t]{2}{*}{ Fungicides } & \multicolumn{6}{|c|}{$\begin{array}{l}\text { Per cent inhibition of radial mycelial growth at concentration } \\
\qquad\left(\mu \mathrm{g} \mathrm{ml}^{-1}\right)\end{array}$} \\
\hline & 50 & 100 & 200 & 400 & 500 & Mean \\
\hline Bitertanol 25WP & $\begin{array}{l}48.40 \\
(44.08)\end{array}$ & $\begin{array}{l}65.90 \\
(54.27)\end{array}$ & \begin{tabular}{ll|}
69.03 \\
$(56.18)$
\end{tabular} & $\begin{array}{l}76.43 \\
(60.95)\end{array}$ & $\begin{array}{l}85.70 \\
(67.78)\end{array}$ & $\begin{array}{l}69.09 \\
(56.16)\end{array}$ \\
\hline $\begin{array}{l}\text { Carbendazim } \\
\text { 50WP }\end{array}$ & $\begin{array}{l}78.16 \\
(62.13)\end{array}$ & $\begin{array}{l}82.70 \\
(65.42)\end{array}$ & $\begin{array}{l}100.00 \\
(90.00)\end{array}$ & $\begin{array}{l}100.00 \\
(90.00)\end{array}$ & $\begin{array}{l}100.00 \\
(90.00)\end{array}$ & $\begin{array}{l}92.17 \\
(73.75)\end{array}$ \\
\hline $\begin{array}{l}\text { Difenconazol } 25 \\
\text { EC }\end{array}$ & $\begin{array}{l}72.30 \\
(58.24)\end{array}$ & $\begin{array}{l}74.00 \\
(59.34)\end{array}$ & $\begin{array}{l}75.38 \\
(60.25) \\
\end{array}$ & $\begin{array}{l}79.43 \\
(63.02)\end{array}$ & $\begin{array}{l}81.90 \\
(64.82)\end{array}$ & $\begin{array}{l}76.52 \\
(61.01)\end{array}$ \\
\hline Hexaconozole 5EC & $\begin{array}{l}50.40 \\
(45.22)\end{array}$ & $\begin{array}{l}65.46 \\
(54.00)\end{array}$ & $\begin{array}{l}72.30 \\
(58.24)\end{array}$ & $\begin{array}{l}80.43 \\
(63.74)\end{array}$ & $\begin{array}{l}87.33 \\
(69.14)\end{array}$ & $\begin{array}{l}71.18 \\
(57.53)\end{array}$ \\
\hline $\begin{array}{l}\text { Myclobutanil } 10 \\
\text { WP }\end{array}$ & $\begin{array}{l}36.33 \\
(37.06)\end{array}$ & $\begin{array}{l}54.70 \\
(47.69)\end{array}$ & $\begin{array}{l}70.22 \\
(56.92)\end{array}$ & $\begin{array}{l}76.23 \\
(60.82)\end{array}$ & $\begin{array}{l}84.46 \\
(66.78)\end{array}$ & $\begin{array}{l}64.38 \\
(53.35)\end{array}$ \\
\hline Mean & $\begin{array}{l}57.11 \\
(49.08)\end{array}$ & $\begin{array}{l}68.55 \\
(55.88)\end{array}$ & $\begin{array}{l}77.33 \\
(61.56)\end{array}$ & $\begin{array}{l}82.50 \\
(65.27)\end{array}$ & $\begin{array}{l}87.87 \\
(69.61)\end{array}$ & \\
\hline $\begin{array}{l}\mathrm{CD}(\mathrm{P}=0.05) \\
\text { Fungicide } \\
\text { Concentration } \\
\text { Fungicide } \times \text { Concen }\end{array}$ & ration & $\begin{aligned} & =(1.27) \\
= & (125) \\
= & (2.33)\end{aligned}$ & & & & \\
\hline
\end{tabular}

Figures within parentheses are arc sign transformed values 
Table.3 In-vitro evaluation of bio-control agents against Fusarium oxysporum f. sp ciceris (Foc) causing wilt/root rot of chickpea

\begin{tabular}{|l|l|}
\hline Bio-control agents & Per cent inhibition in radial mycelial growth of the pathogen \\
\hline Trichodermaviridi -1 & $68.83(56.90)$ \\
\hline Trichodermaviridi-2 & $72.00(58.05)$ \\
\hline Trichodermaviridi-3 & $49.06(44.66)$ \\
\hline Trichodermaviridi-4 & $47.20(43.28)$ \\
\hline Trichodermaharzianum-1 & $54.20(47.40)$ \\
\hline Trichodermaharzianum -2 & $44.40(41.78)$ \\
\hline $\mathrm{CD}(\mathrm{P}=0.05)$ \\
\hline
\end{tabular}

Figures within parentheses are arc sign transformed values

Fig.1 In-vitro evaluation of non- systemic fungicides against Fusarium oxysporum f. sp ciceris (Foc) causing wilt of chickpea

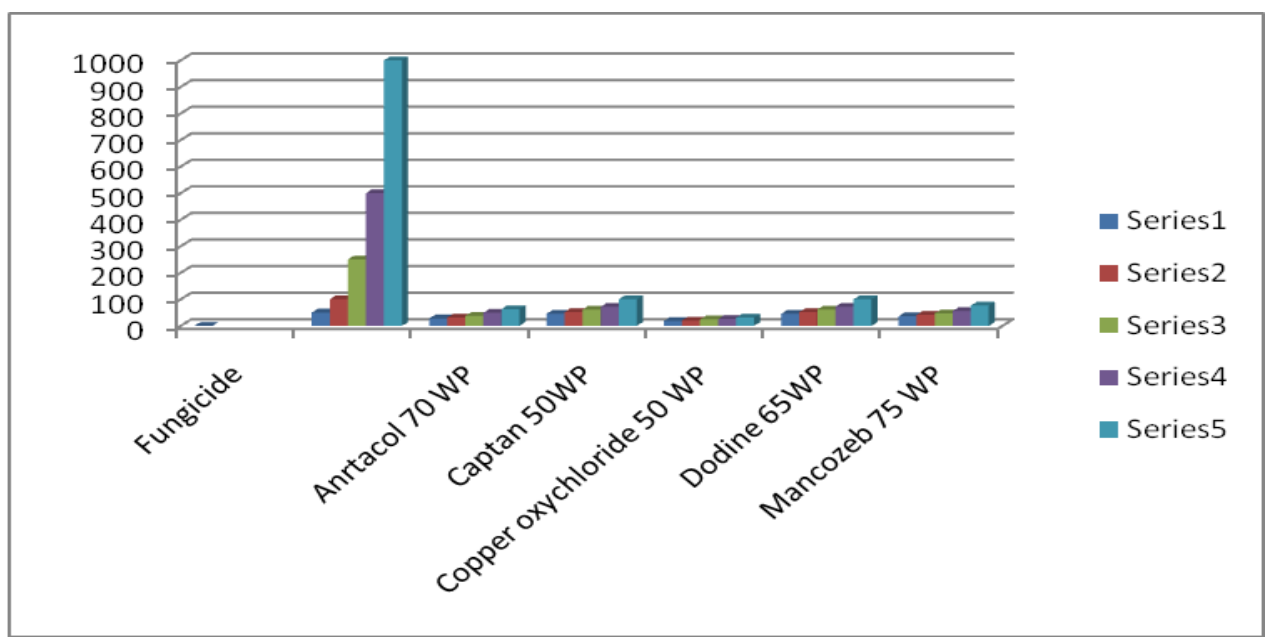

Fig.2 In-vitro evaluation of systemic fungicides against Fusarium oxysporum f. sp ciceris (Foc) causing wilt of chickpea

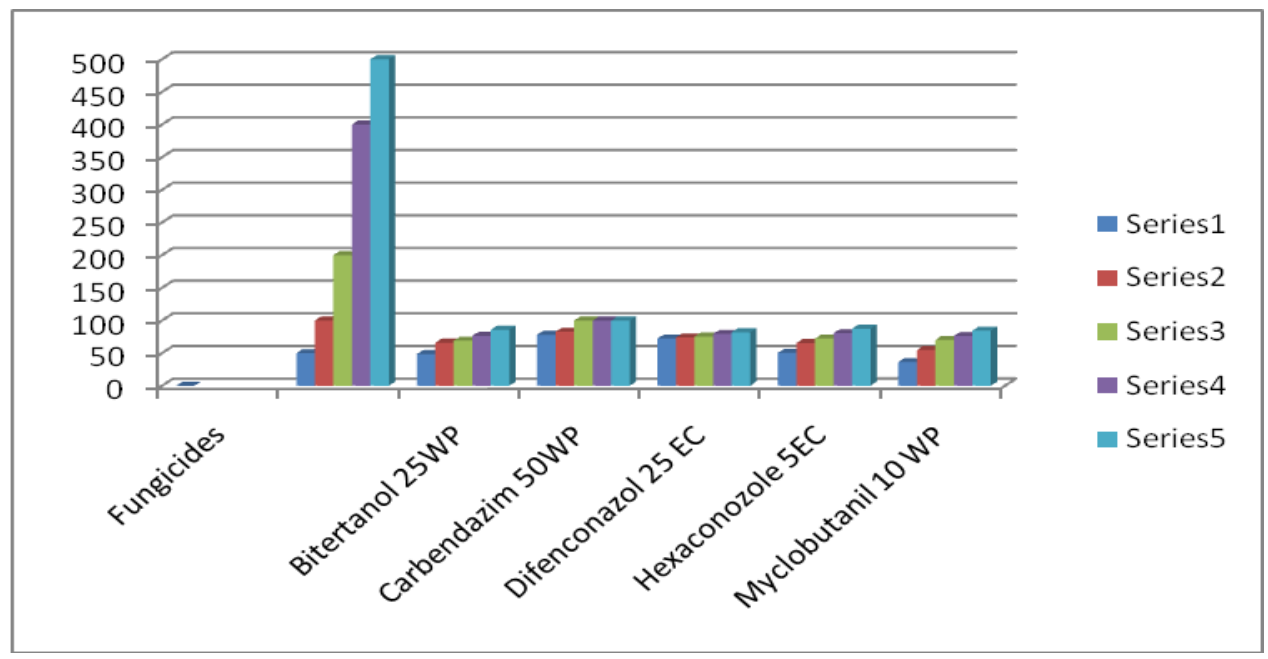


In-vitro evaluation of systemic fungicides on mycelial growth inhibition

Similarly five systemic fungicides were evaluated in-vitro for inhibition of mycelium growth the pathogen (Fusarium oxysporum $\mathrm{f}$. sp. ciceris). The data (Table 2; Fig. 2) revealed that all the test fungicides significantly inhibited the mycelial growth at all the test concentrations. On an overall mean basis, carbendazim 50 WP proved most effective exhibiting mean mycelial growth inhibition of 92.17 per cent followed by difenconozole $25 \mathrm{EC}$ showing 76.52 per cent mean inhibition of mycelial growth while hexaconozole 5 EC caused 71.18 per cent mean inhibition of mycelial growth, respectively. Myclobutanil $10 \mathrm{WP}$ proved least effective resulting in only 64.38 per cent mean inhibition of mycelial growth. In general, the efficacy of fungicides varied significantly with change in fungicide concentration. At $50 \mu \mathrm{g} \mathrm{ml}{ }^{-1}$ concentration, the mean mycelial growth inhibition was 57.11 per cent which increased to 68.55 , $77.33,82.50$, and 87.87 per cent at 100, 200, 400 and $500 \mu \mathrm{g} \mathrm{ml}{ }^{-1}$ concentrations, respectively. The highest mycelial growth inhibition at $50 \mu \mathrm{g}$ a.i ml ${ }^{-1}$ concentration was exhibited by carbendazim $50 \mathrm{WP}$ exhibiting 78.16 per cent mean mycelial inhibition followed difenconazole $25 \mathrm{EC}$ causing 72.30 per cent mean mycelial inhibition while myclobutanil $10 \mathrm{WP}$ was least efficacious and resulted in only 36.33 per cent mean mycelial inhibition. At $500 \mu \mathrm{g} \mathrm{ml}{ }^{-1}$ concentration, 100.00 per cent mycelial growth inhibition was caused by carbendazim $50 \mathrm{WP}$.

\section{In-vitro evaluation of bio-control agents}

In dual culture test of bio-control microorganisms with Foc showed that Trichoderma viridi 2 (Tv2) had more mycelial growth inhibition of pathogen (Foc) with $72.00 \%$ inhibition over control.
Trichoderma viridi 1 (Tv1) was proved to be second best followed by Trichoderma harzianum (Th1), Trichoderma viridi 3 (Tv3) and Trichoderma harzianum 2 (Th2) with $68.83,54.20,49.06$ and 44.40 growth reduction over control respectively (Table 3 ).

Chemical control based on the use of the fungicides in spite of its all health hazards has proved to be the management strategy. Ten chemical fungicides with50-500 ppm were screened against Foc under in-vitro conditions. Out of the ten fungicides carbendazim, dodine and captan were found as the most effective against the Foc. The other fungicides like difenconozole and mancozeb were moderately effective against Foc. Whereas, remaining tested fungicides were generally less effective against the targeted pathogen. Generally, a positive corelation was observed between the different concentrations of the tested fungicides and inhibition of Foc. Higher doses of fungicides were found to be more effective than their lower doses. There were several reports from elsewhere regarding in-vitro evaluation of chemical fungicides $F$. oxysporum. Our results are in conformity with those reported by Ilyas et al., (1992), poddar et al., (2004), Song et al., (2004), Rajput et al., (2006), Mukhtar (2007), Sultana and Ghaffar (2010) and Khan et al., (2012). The fungicides which efficiently inhibit the test fungus in in-vitro study are supposed to be effective against the same pathogen in natural conditions. Generally, all the treatments check the activities of the inoculated fungus (Foc) and hence promote the growth of chickpea plant. Although the higher concentrations of the few fungicides completely inhibited the pathogen. Similarly biological control of the plant diseases can be defined as management of the plant diseases by reducing the inoculum of the pathogen with the help of the beneficial micro-organisms (Campbell, 1994). In the present study Trichoderma viridi was proved 
most effective in in-vitro and these findings were completely in agreement with many workers who found many isolates/strains of Trichoderma, isolated from the rhizosphere regions of host crop plants were found effective to manage the plant pathogens (Burr et al., 1998, Prasad et al., 2002, Postma et al., 2003 and Saikia et al., 2003). Merkuz and Getachew (2012) found that isolates of Trichoderma were very effective against chickpea wilt disease. Singh et al., in 1998 reported that seed treatment of chickpea with bio-control agent like $T$. harzianium and $G$. virens gave best results against F.oxysporum f.sp. ciceri. The present situation demands their incorporation in integrated disease management schedule for better disease management and optimum returns from crop husbandry.

\section{References}

Anonymous. 2013. FAOSTAT. http://faostat 3.fao.org (Accessed on 19-7-2014)

Ayyub, M.A., S.M. Khan, R. Ahmad and K. Iftikhar. 2003. Screening of chickpea germplasm for the sources of resistance against chickpea wilt (Fusarium oxysporum f. sp. ciceris). Pak. J. Phytopathol., 15(1-2): 25-27.

Bakhsh, A., S.M. Iqbal and I.K. Haq. 2007. Evolution of chickpea germplasm for wilt resistance. Pak. J. Bot., 39(2): 583593.

Burr, A., A. Ortuno and T. Armero. (1998). Phosphate solubilizing effect of Aspergillus niger and Pseudomonas. Microbiol. Espanola. 30:113

Campbell, R. (1994). Biological control of soil born disease: some present problems and different approache. Crop Prot. 13:4-13.

Carpenter, J.B., 1942. A toximetric study of some eradicant fungicides. Phytopathology 32: 845.

Chandel, S. and R. Deepika. 2010. Recent advances in management and control of Fusarium yellows in Gladiolus species. J. of Fruit and Ornamental Plant Res., 18(2): 361-380

Chavan, S. C., Y. R. Hegde and S. K. Prashanthi (2009). Management of wilt of patchouli caused by Fusarium solani. J. Mycol. Plant Pathol.39:3234.

Dubey, S. C., M. Suresh and B. Singh (2007). Evaluation of Trichoderma species against Fusarium oxysporum f. sp. ciceris for integrated management of chickpea wilt. Biol. Cont. 40:118-127.

Govil, J.N. and B.S. Rana. 1994. Stability of host plant resistance to wilt (Fusarium oxysporum f. sp. ciceris) in chickpea. Int. J. Trop. Pl. Dis., 2: 55-60.

Haware, M.P. (1990). Fusarium wilt and other important diseases of chickpea in the Mediterriananean area. Options Méditerra néennes - Série Séminaires. 9:61-64.

Ilyas, M.B., M.J. Iqbal and K. Iftikhar. 1992. Evaluation of some fungicides against Fusarium oxysporum f. sp. ciceris and chickpea wilt. Pak. J. Phytopathol., 4(12): 5-8.

Jamil, S. and M. Kumar. 2010. Evaluation of fungicides against phyllosphere mycoflora of foliage plants. Biological Forum, 2(1): 56-59.

Khan, H.S.I., M. Saifulla, A.S.N. Nawaz, P.R. Somashekharappa and R. Razvi. 2012. Efficacy of fungicides and biocontrol agents against Fusarium oxysporum f. sp. ciceris causing wilt of chickpea. J. Enviro. Ecol., 3: 570-572.

Merkuz, A. and A. Getachew (2012). Epidemic of Fusarium wilt (Fusarium oxysporum f. sp. ciceris) of chickpea at wilt sick plot in adetethiopia. Int. J. Curr. Res. 4(05):135-141.

Mukhtar, I. 2007. Comparison of phytochemical and chemical control of Fusarium oxysporum f. sp. ciceris. Mycopath, 5(2): 107-110. 
Navas-Cortés, J.A., B.B. Landa, M.A. Méndez-Rodríguez and R.M. JiménezDíaz (2007). Quantitative modeling of the effects of temperature and inoculum density of Fusarium oxysporum f. sp. ciceris races 0 and 5 on development of Fusarium wilt in chickpea cultivars. Phytopathol. 97(5):564-573.

Poddar, R.K., D.V. Singh and S.C. Dubey (2004).Integrated application of Trichoderma harzianum mutants and carbendazim to manage chickpea wilt (Fusarium oxysporum f. sp. ciceri). Ind. J. Agric. Sci.74:346-348.

Postma, J., M. Montanari and J. F. Van den Boogert (2003).Microbial enrichment to enhance disease suppressive activity of compost. Eur. J. Soil Biol. 39:157-163.

Prasad RD, Rangeshwaran R, Anuroop CP, Rashmi HJ (2002). Biological control of wilt and root rot of chickpea under field conditions. Ann Plant Prot Sci 10: 72 75

Rajput, A.Q., M.H. Arain, M.A. Pathan, M.M. Jiskani and A.M. Lodhi. 2006. Efficacy of different fungicides against Fusarium wilt of cotton caused by Fusarium oxysporum f. sp. vasinfectum. Pak. J. Bot., 38(3): 875-880.

Ryan, J.G. 1997. A global perspective on pigeon pea and chickpea sustainable production systems-present status and future potential. In: Recent Advances in Pulses Research. (Eds.): Asthana A.P. and M. Ali. Indian Society of Pulses Research and Development, Kanpur, India. pp. 1-31.

Saikia R., T. Singh, R. Kumar, J. Srivastava, A.K. Srivastava, K. Singh and D.K. Arora. (2003). Role of salicylic acid in systemic resistance induced by Pseudomonas fluorescens against Fusarium oxysporum f. sp. ciceri in chickpea. Microbiol. Res. 158:203-213.

Singh, U.S., A.N. Mukhopadhayay, J. Kumar and H.S. Chaube. 1998. Prentice Hall, Englewood Cliffs, NJ. pp. 429-444.

Song, W., L. Zhou, C. Yang, X. Cao, L. Zhang and X. Liu. 2004. Tomato Fusarium wilt and its chemical

Sultana, N. and A. Ghaffar. 2010. Effect of fungicides, microbial antagonists and oilcakes in the control of Fusarium solani, the cause of seed rot, seedling and root infection of bottle gourd, bitter gourd and cucumber. Pak. J. Bot., 42(4): 2921-2934.

Trapero-Casas and Jimenez-Diaz, R.M. 1985. Use of fungicide treatments and host resistance to control the wilt and root rot complex of chickpeas. Plant Disease, 69: 591-595.

\section{How to cite this article:}

Sabiya Bashir, Mohammad Najeeb Mughal, Sher A. Dar, Seerat un Nissa, Shafeeq Hakeem, R.A. Wani, J.A. Baba and Mehfooza Habib. 2017. In vitro Efficacy of Fungicides and BioControl Agents against Wilt of Chickpea Caused by Fusarium oxysporum f. sp. ciceris (Foc). Int.J.Curr.Microbiol.App.Sci. 6(11): 1392-1399. doi: https://doi.org/10.20546/ijcmas.2017.611.166 